\title{
Corporate Finance in Europe: A Survey ${ }^{1}$
}

Francois Degeorge

University of Lugano

Via Giuseppe Buffi 13

CH-6904 Lugano

Switzerland

Email: francois.degeorge@lu.unisi.ch

Tel: +41 (58) 6664634
Ernst Maug ${ }^{2}$

School of Business Administration

University of Mannheim

L 9, 1-2

D-68165 Berlin, Germany

Email: maug@cf.bwl.uni-mannheim.de

Tel: +49 (621) 181-1952

This draft: Thursday, March 23, 2006

\section{Introduction}

This survey takes stock of research on corporate finance in Europe. The ambition is to provide the reader with an overview of what we learned about the subject, particularly since the beginning of the 1990s. We focus on two themes when studying corporate finance in Europe. Firstly, the practice and institutions in Europe are heterogeneous and different from those in the United States and we demonstrate the importance of this observation. Secondly, we wish to draw some more general conclusions with respect to the law and finance paradigm that has dominated recent research on comparative institutional analysis, and the diversity of European institutions seems to present an ideal testing ground for this approach.

The body of research on corporate finance is large and the subject has many facets, so we selected some topics that we deem important and that provide a particular European perspective. As a result, we do not include extensive discussions of theoretical developments unless they grapple with specifically European issues and we discuss research on other countries only in order to provide comparisons and to put European research in context. We refer the reader to the excellent and extensive surveys in Constantinides, Harris, and Stulz

\footnotetext{
1 We are grateful to Colin Mayer (the editor) for helpful comments on an earlier draft of this chapter. Degeorge acknowledges Financial support by the National Centre of Competence in Research "Financial Valuation and Risk Management" (NCCR FINRISK). The NCCR FINRISK is a research program supported by the Swiss National Science Foundation. Maug thanks the Rudolph von Bennigsen-Foerder-foundation for financial support and Thomas Diete and Karmonthip Wichmann for excellent research assistance.

2 Corresponding author.
} 
(2003) for comprehensive general surveys on topics in corporate finance we cover here. Even with this limited scope we make no pretense to be comprehensive, and we focus on articles that test hypotheses that emerge from the European context and that exploit European institutional features. We selectively include articles that mainly replicate simlar research on the United States for Europe or for single European countries.

We warn the reader that "Europe" in the sense of this survey article is not a well-defined, homogeneous geographical region, and is heterogeneous with respect to the institutions under study here. To some extent this is what makes research on Europe fascinating. For example, Rajan and Zingales (2003) point to a North-South divide in the financial development indicators of European countries. A basic analysis of the financial indicators of La Porta et al. (1997, 1998, henceforth LLSV) suggests that their variation across legal systems within Europe is even greater than outside Europe - in spite of the fact that European countries share similar economic development histories. In order to simplify our task - and given the scarce research available to date - we omit former communist countries from our survey.

We address in turn: equity primary markets; privatizations; cross-listings; capital structure and payout policy; mergers and acquisitions; business groups, pyramids and dual class shares; and valuation and the cost of capital.

\section{Equity primary markets}

\subsection{The decision to go public}

European research on equity primary equity markets has been quite active in the past decade. Several papers have exploited European institutional features, or access to confidential data, to address issues of wide relevance. 
Pagano, Panetta, and Zingales (1998) tackle the issue of why firms go public. Surprisingly, this question had received fairly little academic attention. Their study uses an Italian sample of IPOs - and most importantly, a control sample of privately-owned Italian companies, for which they obtain confidential data from the Bank of Italy. They find that the main factor affecting the probability of an IPO is the market/book ratio at which firms in the same industry trade. This could be due to the higher investment needs of sectors with high growth opportunities. It could also reflect an attempt by issuers to time the market. The latter explanation gains additional weight from the fact that investment and profitability decrease on average after the IPO.

Pagano et al. document that independent companies experience a reduction in cost of bank credit after the IPO (40 to 70 basis points) - even when controlling for firm characteristics and for reduction in leverage after going public (30 to 55 basis points). Moreover, after the IPO, firms borrow from a larger number of banks: the reduced cost of credit could be due to better public information associated with exchange listing or a stronger bargaining position vis-à-vis banks.

How generalizable are the conclusions from this Italian study? The typical Italian IPO is much larger and older than its U.S. equivalent. But this is true also of other European countries (e.g. see Rydqvist and Högholm 1995 on Sweden), and Italian IPOs are not unlike mature U.S. IPOs (for example, like reverse LBOs in the U.S., Italian IPOs use the proceeds more to rebalance accounts than to finance growth). Italy certainly differs from the U.S. by the small size of its stock market relative to its economy. Most continental European countries share this feature, which points to a broader question: why does the stock market cater to large, mature companies in Continental Europe, while the opposite is true in the U.S.? There are several possible, not mutually exclusive answers. One, popular ten years ago, 
was that appropriate stock markets were lacking in Europe. Since then, several markets specifically targeted to small, innovative firms have been launched. Their success has been mixed: the German Neuer Markt has closed, and the French Nouveau Marché has been merged. The line of work of LLSV suggests another answer: if minority shareholder protection is low in some countries - and broadly speaking, that tends to be true in Continental Europe - then external equity finance is expensive to raise.

Recent work by Fama and French (2004) adds a new perspective on this debate. They document that the annual number of new issues has considerably increased in the U.S. since the early 1970s, due to an apparent decline in the cost of equity that allows weaker firms, and firms with more distant expected payoffs, to issue public equity. Why this change occurred in the U.S., and not in Europe, is a fascinating open question for future research. Note that the change in the U.S. is not necessarily for the better. If U.S. IPOs are overpriced (Purnanandam and Swaminatham 2004, Loughran and Ritter 1995), the lower number of IPOs observed in Europe might actually be closer to the economic optimum. ${ }^{3}$

On the whole European IPOs are more mature firms and smaller and younger firms generally do not go public in Europe as much as they do in the United States. Three explanations have been advanced to explain this observations, all with radically different implications: (1) Europe has weaker investor protection (implying that U.S. practice is superior), (2) IPOs are overpriced in the U.S., creating to strong an incentive to go public (implying that U.S. practice is inferior), and (3) falling cost of capital have led to more IPOs in the U.S., but not in Europe, which then raises the question if the cost of capital are higher in Europe than in the U.S., which would deserve further investigation.

3 See Fama and French (2004) pp. 268-270 for a discussion of this point. 


\subsection{Developments of IPO mechanisms}

In the United States, book-building is the traditional method for taking companies public. A price range is set; the underwriter collects non-binding bids from investors; the final price is set; and the underwriter allocates the shares with complete discretion. Book-building has attracted a fair amount of criticism in recent years. A first line of attack centered on fees. Chen and Ritter (2000) document that bankers' fees are exactly equal to 7\% of IPO proceeds for a surprisingly large number of deals. While the interpretation of these high fees is still controversial (see Hansen, 2001) it is interesting to note that over the past decade, bookbuilding has become more wide-spread world-wide. As Ljungqvist, Jenkinson, and Wilhelm (2003) document, outside the U.S., book-building is more expensive in fees than the traditional fixed-price methods. They argue that book-building provides a benefit to issuers in the form of more accurate pricing: once they control for the endogeneity of the choice of IPO procedure, they find that - especially when it is combined with a U.S. underwriter and a U.S. investor clientele - book-building can reduce underpricing significantly.

One of the salient characteristics of the book-building procedure is the discretion that underwriters and issuers enjoy in allocating shares. While this feature has recently attracted controversy in the context of IPO scandals in the United States ${ }^{4}$, a body of corporate finance theory suggests that the discretion enables underwriters to reward investors for revealing private information about the value of the firm taken public (e.g. Benveniste and Spindt 1989). The confidentiality of IPO share allocations makes it difficult to test directly whether underwriters indeed allocate shares to investors providing positive information, but a few European papers take a stab at this issue. Cornelli and Goldreich (2001) use a unique dataset of investor bids and allocations for 39 international equity issues managed by a major European investment bank. Their evidence supports the view of bookbuilding as an 
information extraction mechanism: the investment banker awards more shares to bidders who reveal information through limit prices than to other bidders. In another paper using a European sample of 63 international equity issues, Cornelli and Goldreich (2003) find that the bids that most influence the issue price are the ones that are favored in the allocation of shares - consistent with the view that investors supply information in exchange for a more favorable allocation. By contrast, Jenkinson and Jones (2004) find little evidence that more informative bids (that is, limit orders, revised bids, or bids submitted early in the bookbuilding period) receive preferential allocation. Jenkinson, Morrison, and Wilhelm (2005) suggest that in Europe information revelation by investors may occur before the IPO prospectus is issued, rather than during the book-building period per se (for regulatory reasons this is not possible in the U.S.). This would also explain why very few European IPOs are eventually priced outside the initial range: unlike in U.S. IPOs., the initial range in European IPOs already benefits from the information collected from investors.

European markets offer a useful perspective on the issue of what is the best way to offset the asymmetric information problem plaguing IPOs. For example, while IPO auctions are rarely used in the United States, they have long been used in France. Book-building has also been used in France since it was introduced in the early 1990s, so that the French IPO market offers an interesting setting in which to compare the costs and benefits of book-building vs. auctions. Derrien and Womack (2003) find that IPO auctions in France exhibit a smaller mean and variance of underpricing. Therefore, one of the important costs of going public, underpricing, seems to be lower for auctions compared to book-building. Underwriter fees tend to be lower for auctions too. Since IPO auctions exhibit no noticeable difference in longterm performance relative to book-building (Degeorge and Derrien, 2001) it is hard to argue that the higher costs paid by issuers choosing book-building are somewhat offset by valuation

4 One of the controversies centered on the practice of "spinning”, i.e. allocating shares of underpriced IPOs to 
advantages. Nor are the results driven by intrinsic firm characteristics, as they are robust to controls for endogeneity in the choice of IPO procedure.

Overall then, the growing dominance of book-building as the preferred IPO procedure in Europe raises a puzzle: book-building entails higher fees than auctions (the main competitor to book-building where more than one procedure exists); it is associated with more underpricing; and the discretionary power of the underwriter in share allocation makes the procedure prone to abuse. Yet in all countries where book-building has been introduced recently, pre-existing auction mechanisms have disappeared or lost significant market share (Sherman, 2003). Even if book-building works well to extract information from investors, it is not obvious that well-designed auction mechanisms could not perform the same function (Biais, Bossaert, and Rochet, 2002, Biais and Faugeron-Crouzet 2002). Why then have auctions become less popular in IPOs? Degeorge, Derrien, and Womack (2005) offer an “analyst hype” explanation for this puzzle. They hypothesize that issuers are willing to pay the higher cost of book-building in exchange for increased and more favorable research coverage, and find confirming evidence. Their findings, while based on a French sample, have relevance outside Europe - in particular for the U.S., where the 2004 Google IPO auction has revived the interest in IPO auctions.

While auctions have received much attention lately, they are not the only alternative to the standard book-building procedure. Derrien and Kecskés (2005) exploit a characteristic of the UK primary equity market: firms can list without issuing equity, and issue equity thereafter. Such listings are called "introductions." A market price for the equity is nevertheless established through transactions between current shareholders and anyone who wishes to buy shares in the firm. They argue that the existence of a market price reduces uncertainty about the firm's value, and should result in lower levels of initial returns when the firm offers 
shares for sale to the public. Indeed, they find that initial returns for these firms are 10 to 33 percentage points lower than for comparable IPOs. Their results are robust to endogeneity controls, suggesting that firms might be able to save on underpricing costs by considering this unusual two-stage method of going public.

While much of the IPO literature focuses on the issue of how to incorporate private information into the IPO price, Derrien and Womack (2003) document that market conditions (measured by the market return in the months before the offering) have a much greater positive - impact on IPO underpricing for book-built offerings than for auctioned offerings. So, auctioned IPOs appear to be better at incorporating public information than book-built IPOs. Because it relies on semi-strong form market efficiency, the traditional asymmetric information paradigm is silent on the issue of whether some IPO procedures do better than others at incorporating public information into the IPO price. A behavioral perpective on IPO pricing provides some insight here. Derrien (2005) argues that IPO prices are influenced by investor sentiment. Overly bullish noise traders drive up the price, but the underwriter is reluctant to fully incorporate investor sentiment in the IPO price, because he worries that when investor sentiment vanishes, he will have to pay the cost of price support. In this behavioral framework IPO initial returns may be influenced by market conditions. Derrien finds support for this framework on a sample of French IPOs using the Offre à Prix Ouvert, a unique IPO mechanism in which a fraction of the IPO shares is reserved for individual investors.

In a similar vein, Cornelli, Goldreich, and Ljungqvist (forthcoming 2005) use a unique institutional feature of the European IPO market to test behavioral theories of IPO market pricing. They focus on the grey (or "when-issued”) market in European IPOs, which enables investors to speculate on the future stock prices of companies that are about to go public. The 
grey market starts when issuers publish the filing range, and ends when the IPO starts trading. From a behavioral perspective the grey market is interesting because it primarily attracts small investors. A high grey market price indicates small investor optimism. Cornelli et al. find that high grey market prices are a good predictor of first-day aftermarket prices, while low grey market prices are not. Moreover, IPOs with high grey-market prices experience long-run price reversals. Their findings are consistent with a story in which sophisticated book-building investors sell their shares to small investors if the latter are overoptimistic, but not if they are overly pessimistic.

In the final conclusion, the demise of traditional offering methods in Europe in favor of bookbuilding still presents a puzzle that has not been resolved completely. Clearly, this is an area where European practice has converged to that of the U.S. and where institutional heterogeneity has been diminished during the last decade.

\section{Privatizations}

The privatization of state-owned companies has been one of the major economic transformations of the past two decades, involving many countries. Several multi-country studies of privatizations use samples that include Europe, although they often reach far wider. Megginson and Netter (2001) offer an excellent survey of empirical studies on privatization around the world. We limit ourselves to studies with a more European focus, and we emphasize work that appeared after their survey.

The large literature on privatizations falls into several categories: the determinants of privatizations; how privatizations are done; post-privatization performance; and the impact of privatizations. In Western Europe privatizations have usually been done through share issues, while voucher privatization schemes have often been used in former communist countries. Bortolotti, Fantini, and Siniscalco (2003) find that share issue privatizations are all the more 
common as the government is conservative and government deficit is high. They also find that governments from French civil law countries are less likely to privatize, other things being equal. Jones, Megginson, Nash and Netter (1999) document that governments often use share-issue privatizations for political ends. Governments typically tilt allocation patterns toward domestic investors, impose control restrictions, and underprice the shares at the offering - but probably for very different reasons than the typical IPO (possibly to pick up votes from voters in the process - see Biais and Perotti, 2002).

Keloharju, Knüpfer, and Torstila (2005) analyze in detail the incentives given to retail investors. They find that many countries use bonus schemes and discounts to increase investor participation in privatizations, and that they increase investor participation much more cost-effectively than underpricing - although it is still costly (up to \$248 per additional investor!). Degeorge, Jenter, Moel, and Tufano (2004) analyze the case of the France Telecom privatization in 1997. They find that inducing employees to participate was no easy task: in spite of various incentives amounting to a $80 \%$ discount, one third of the employees did not participate.

Many studies document increases in performance in privatized companies (see for example D’Souza and Megginson (1999) and the studies summarized therein). Interestingly, however, Bortolotti, and Faccio (2005) find that greater government control of the firm postprivatization tends to be associated with higher market valuations. This puzzling finding is hard to square with accepted theories of privatizations.

Finally, a number of studies examine the impact of privatizations on stock market development. A general theme is that privatization increases stock market capitalization, trading, and participation by individual investors in the stock market (see Megginson and Netter, 2001). Whether this last phenomenon will survive the bull market of the 1990s is 
unclear. In France for example, the France Telecom privatization brought many first-time investors to the stock market. Anecdotal evidence suggests that the subsequent crash in the France Telecom stock may have done lasting damage to individual investors’ appetite.

Privatizations present a multi-faceted phenomenon, and not many clear conclusions emerge as governments pursue privatizations with different political objectives (government deficits, developing stock markets, broadening stock ownership, reducing the involvement of government in economic activity) and accordingly with different results.

\section{Cross-listings}

Cross-listings of companies have attracted increasing attention by researchers and regulators in recent years. Here we use a broad definition of cross-listings, encompassing all companies where at least one class of stock is listed on an exchange in a country other than the country of incorporation. Pagano, Roell, and Zechner (2002) document that in the years from 19861997, European companies have become more mobile and increasingly listed on foreign exchanges, with the U.S.-exchanges being the primary destination: during this time, the number of listings of companies from the EU9 in the U.S. almost quadrupled from 53 to 207, while the number of cross-listings within the EU9 increased from 267 to 309. At the same time, U.S. companies have reduced their listings in Europe, and foreign listings from all countries in the EU9 went down.

Researchers have followed several paradigms in order to explain why companies list abroad, what benefits this activity generates, which types of companies list and what characteristics explain their listing choices. Of particular interest here is the increased attractiveness of the U.S. and the reduced attractiveness of Europe as a destination for cross-listings. The law and finance literature views cross-listings as a method to bond companies to a higher corporate governance standard by listing on an exchange that imposes tighter governance and 
disclosure standards (Coffee, 1999). ${ }^{5}$ Evidence in favor shows for example that managers and large shareholders of foreign companies that do not cross-list in the U.S. differ from those of non-U.S. companies that do list in the U.S.: cross-listing firms enjoy smaller private benefits of control and their managers have fewer control rights (Doidge, Karolyi, Lins, Miller, and Stulz, 2005). The bonding hypothesis also seems to be supported by the fact that companies with ADR-listings in the U.S. attract more investment funding after the listing (Reese and Weisbach, 2002). Doidge, Karolyi, and Stulz (2004) also document that U.S.-listed firms enjoy a cross-listing premium, which is larger for firms with larger growth opportunities, and that these growth opportunities are larger for firms from countries that rank low on the LLSV investor protection scale. Nonetheless, the bonding hypothesis of cross-listings is subject to a number of reservations. With respect to U.S.-listings, the argument relies crucially on the notion that a cross-listing subjects the company to U.S. securities laws. Siegel (2004) shows that this is generally not the case and foreign companies do obtain significant exemptions from SEC rules. He shows in particular that there is no evidence that minority shareholder protection is enhanced. A closely related argument pertains to disclosure standards. Here, Pagano, Roell, and Zechner (2002) document that European firms list on exchanges where they are subject to lower accounting standards than at home, a fact that is largely driven by British companies: UK accounting standards are excellent and many UK firms list abroad. Licht (2003) goes even further and argues that Israeli companies list in the U.S. precisely in order to benefit from less stringent disclosure requirements in the U.S. and in order to avoid the "disinfecting sunlight” imposed by domestic regulations. Licht formulates the alternative “avoiding hypothesis” according to which firms regard higher disclosure standards as a cost, a claim that is also supported by the survey of Bancel and Mittoo (2001). In their survey of foreign listings from 6 European countries, they found that the primary benefits cited by

5 The bonding hypothesis of listing choice in a purely domestic context can be traced back at least to Gordon (1988), who argues that listing on the NYSE commits the firm to a single-class share structure. 
managers are increased visibility and growth of the shareholder base, whereas SEC compliance and reporting requirements are viewed as a cost.

For European companies, the patterns of cross-listings seems to be better explained by other considerations. Pagano, Randl, Roell, and Zechner (2002) show that more liquid markets with lower trading costs attract more foreign listings, which potentially also explains the attractiveness of the U.S.. The importance of the liquidity of deep markets may also explain why they find that many cross-listings are privatized companies that plan future sales of their shares. Within Europe, geographical and cultural proximity seem to play a significant role: $57 \%$ of all European cross-listings take place within regions defined by close cultural and linguistic ties, compared to $24 \%$ that would be expected if listings were distributed randomly (Pagano, Roell, Zecher, 2002). This is supported by related findings by Portes, Rey, and Yonghyup (2001) who investigate international cross-border equity flows and show that these flows depend negatively on geographical distance, a finding that they relate to informational frictions. Portes et. al. also show that companies that list in the U.S. are typically fast-growing high-tech companies, which possibly receive better expert attention by analysts on the U.S. market. This argument accords well with the finding that European companies that list in the U.S. are significantly more likely to make acquisitions in the U.S., and are more likely to use stock when paying for acquisitions, compared to their domestically listed peers (Tormunen and Torstila, 2005). By comparison, the Pagano, Roell, Zechnerstudy shows that companies that cross-list within Europe are more likely to be mature companies that do not grow fast and increase their leverage after cross-listing. In an earlier study, Saudagaran (1988) found also significant relationships between cross-listings and the proportion of foreign sales, documenting that product market considerations are also relevant. The bonding hypothesis cannot explain why European exchanges have become less attractive over the last decade - investor protection and disclosure standards in Europe have, if 
anything, increased. It is conceivable that changes in cross-listing decisions are influenced by related changes in product markets and trade flows, but we are not aware of any study that has tested this hypothesis. Listings in the U.S. may have become more attractive for European companies for the same reasons that they became so for U.S. companies (see our discussion of Fama French, 2004, above).

The overall evidence on cross-listings is somewhat mixed. Whereas some papers come out clearly in favor of the bonding hypothesis, others cast doubt on its premises and emphasize alternative reasons and mechanisms like liquidity, trading costs., and product market considerations. Moreover, most of the evidence supporting the bonding hypothesis is somewhat indirect, drawing conclusions from control rights, patterns of cross-listings, and investment funding. The challenge to future research seems to be to find more direct evidence to settle this debate.

\section{Capital structure and payout policy}

Differences in accounting rules create many challenges for an empirical study of capital structure at the European level - so much so, in fact, that to the best of our knowledge no such academic study exists. Nevertheless, Rajan and Zingales (1995) do a careful analysis of capital structure in a sample of G-7 countries, which contains four major European countries (France, Germany, Italy and the United Kingdom). In particular, they adjust the data for differences in accounting standards. Several interesting patterns emerge. First, firms in the United Kingdom and Germany have lower leverage than in France and Italy, independent of company size. Institutional differences probably explain some of the cross-country differences. For example, creditor protection is higher in Germany and the UK than in France and Italy, and that might be the reason for the lower levels of leverage in the former two countries: firms may be less likely to lever up if they anticipate that they will be 
automatically liquidated in case of bankruptcy. Second, the factors affecting leverage are remarkably similar across countries. Asset tangibility is positively correlated with leverage presumably because tangible assets can better serve as collateral. Market-to-book (a proxy for investment opportunities) is negatively correlated with leverage. This finding is consistent with the idea that highly levered companies are more likely to pass up profitable investment opportunities; it is also consistent with firms attempting to time the market and to issue equity when they perceive their stock price to be high. Rajan and Zingales also report a puzzling finding: size is positively correlated with leverage in all countries except Germany. While theory gives ambiguous predictions on the relation of size to leverage, why the relation in Germany should run opposite to that in other countries is not clear. The authors conclude that "a deeper understanding of the actual determinants of the effects of institutional differences is necessary."

Bancel and Mittoo (2004) take a stab at this issue using a survey approach. Similar to Graham and Harvey (2001) for the U.S., they interview chief financial officers in 16 European countries. Their results suggest that European and U.S. managers use similar criteria in making their financial decisions: they find modest support for the tradeoff and pecking order theories of capital structure, and almost no support for the asset substitution and free cash flow hypotheses. ${ }^{6}$ Within Europe, there are differences both across and within legal systems as defined by La Porta et al. $(1997,1998)$.

Survey evidence by Bancel, Bhattacharya, and Mittoo (2005) indicates that European managers' views on payout policy are largely similar to those of their U.S. peers (Brav, Graham, Harvey, and Michaely, 2004). The two most important determinants of dividend policy are the stability and level of future earnings, and an aversion to cutting dividends. But

6 Brounen, de Jong, and Koedijk (2004) find similar results in a survey of CFOs from the U.K., the Netherlands, Germany and France. 
as in the case of capital structure, some cross-country differences emerge, not easily explained by differences in legal systems. For example, German managers are much less concerned with cutting dividends than their peers in civil law countries. Perhaps German banks use their influence over German companies to protect their creditor claims (Amihud and Murgia (1997), Correia da Silva, Goergen, and Renneboog, 2005).

Relative to the U.S., repurchases have been less common in Europe. The practice has recently picked up, however, and more academic studies of European repurchases are likely to appear. $^{7}$

Compared to other issues in corporate finance, payout policy and capital structure policy seem to be much more homogeneous across Europe with only a moderate influence of institutional differences, possibly with the notable exception of Germany. The factors drving capital structure and payouts are similar to those in the U.S., and the increasing importance of repurchases provides further evidence for convergence. Interestingly, agency-based explanations like the free cash flow approach and asset substitution receive less support from survey-based evidence than asymmetric information approaches.

\section{Mergers and acquisitions}

Goergen and Renneboog (2004) study the European M\&A-market in the 1990s by analyzing a sample of 187 large mergers and acquisitions in 18 European countries as well as some aggregate statistics. They establish many results that are similar to those from previous studies on the M\&A-market in the United States. Event study results reveal that investors owning a target company from 40 trading days before an acquisition announcement until the end of the event day realize average abnormal returns of $23.1 \%$. The same number is $0.4 \%$

7 For example, Ginglinger and Hamon (2005) exploit stringent French disclosure requirements to perform a study of actual repurchases by companies of their stock. They find that companies purchase against market trends, and that repurchases are associated with a decline in stock liquidity. 
for bidders. Cash offers are associated with larger announcement effects than acquisitions with stock or other securities. Announcements of mergers and friendly acquisitions generate similar returns over the same event window (23.4\% and 20.3\% respectively), whereas market reactions for hostile acquisitions are larger (29.2\%), confirming related evidence for the U.S.. Surprisingly, however, multiple bidder contests do not generate significantly larger returns. Also, in all cases the pre-announcement run-up over 40 trading days seems to be large: across all types of announcements, the cumulated return over the $(-1,0)$-event window is less than $40 \%$ of the return over the larger $(-40,0)$-window, potentially indicating that insider trading regulations and enforcement are not as strict in Europe as they are in the U.S.. Shareholders of bidding companies benefit from mergers and friendly acquisitions (abnormal returns starting 40 trading days before the announcement of $4.6 \%$ and $4.8 \%$ respectively), but suffer losses from hostile bids by their companies (-2.5\% abnormal announcement return). There are also regional differences within Europe. Shareholders of UK targets benefit more than those from Continental Europe, with the difference being statistically significant for all event windows. Results are not statistically significant for bidding firms, although acquirers of southern European targets tend to benefit less than those of German and central European targets.

A second set of studies investigates how mergers and acquisitions in Europe affect other stakeholders, like consumers and workers. Gugler and Yurtoglu (2004) analyze the impact of mergers on employment in a sample of 646 mergers in the 1987-98 period. They find that firms in the U.S. have pre-merger labor-productivity similar to non-merging firms, and mergers in the U.S. have no impact on employment. By contrast, in Europe, merging partners have labor productivity $9 \%$ below their non-merging industry peers before the merger, and they increase their labor productivity by $10 \%$ to the industry average through layoffs after the merger. The authors explain this fact by differences in labor markets: mergers in Europe 
serve to break implicit contracts and overcome labor market rigidities, whereas no such implicit contracts need to be broken in the U.S. where labor markets are more flexible. Surprisingly, the effect is stronger in the UK than in Continental Europe. The authors attribute this finding to the U.K.s comparatively less flexible labor markets.

Focarelli and Panetta (2003) analyze if mergers harm consumers by investigating how the deposit rates of Italian banks are influenced by mergers. Controlling for a number of factors, they show that the anti-competitive effect of mergers is short-lived: while deposit rates decline in the year of the merger, they increase eventually. This supports the hypothesis that mergers create efficiency gains that are passed on to consumers in the long run.

Regulating the impact of mergers on consumers is the role of competition authorities, and within Europe this role rests with the European commission for large mergers. ${ }^{8}$ The role of the European commission in this regard has caught the attention of researchers as well as politcal commentators, in particular since the commission has recently also regulated mergers among companies not domiciled in the EU. ${ }^{9}$ Aktas, de Bodt, Levasseur, and Schmitt (2001) point out in their analysis of the Boeing - Mc Donnell Douglas-acquisiton the European Commission's increasing tendency to show its strength even in non-European mergers. This is supported by an important difference in legal rules: The European commission can block a merger, whereas the U.S. system requires that the competition authorities obtain the consent of a judge for a ban (Aktas de Bodt, Levasseur, and Schmitt, 2001). Aktas, de Bodt, and Roll (2004a) analyze 604 merger cases investigated by the European Commission in the 19901999 period, of which 101 involved only non-EU firms. The commission proceeds in two

8 The rules specify that the merging partners have to pass a size threshold. A minimum proportion of their sales that must be in at least two EU countries for the commission to be responsible, otherwise national authorities are in charge. The domicile of the firms is irrelevant for this question.

9 In the Boeing-Mc Donnell Douglas case, the European Commission forced Boeing to give up some exclusivity contracts with European airlines, which implied a significant loss of value for Boeing shareholders. Other well publicized cases included the merger of General Electric with Honeywell and the EMI/Time Warner-deal. 
stages, where most decisions are reached in first stage after a maximum of one month, and only few cases are scrutinized more closely in the second stage that can take up to four months. The Aktas, de Bodt, and Roll-study shows that concluding stage 1 is generally accompanied by positive stock market reactions for all companies, particularly for targets, whereas entering stage 2 is accompanied by losses for all companies concerned. Large returns on the initial announcements seem to indicate large monopoly rents and are more likely to lead to more thorough stage-2 investigations. The study also investigates which variables predict the decision of the commission. They find that approval is positively associated with size, which the authors attribute to the better bargaining position of large companies. Also, higher announcement returns predict success, which indicates that firms bargain more successfully with the commission if more value from the deal is at stake. In a follow-up study, Aktas, de Bodt, and Roll (2004b) analyze a sample of 290 merger cases where both parties are listed companies and demonstrate that the commission is more likely to block mergers where European companies are harmed from increased competition, and also if the bidder is a foreign company, lending support for the claim that the commission's policy is protectionist.

European markets for mergers and acquisitions present some rather striking differences to their U.S. counterparts. While some are easily explained by institutional differences (difference in the protection of stakeholders other than shareholders, competition law), others (premia for hostile bids) are more surprising. Anecdotal evidence suggests that some separation of national markets and therefore institutional heterogeneity are likely to persist. We would like to see more studies that investigate how well the European market for corporate control performs relative to other regions and how it contributes to the performance of European economies. Research on mergers and acquisitions in Eastern Europe is, to the best of our knowledge, non-existent. 


\section{Business Groups, Pyramids, and Dual Class shares}

Several European studies have investigated the organization of firms into business groups through pyramidal forms of ownership and cross-shareholdings. Interestingly, with the notable exception of Faccio and Lang (2002), all studies focus only on one European country. Studies in this area focus on one (and sometimes both) of two aspects. The first aspect emphasizes how holding companies and business groups act as internal capital markets that may be useful (if they reduce transaction costs) or harmful (if they lead to inefficient crosssubsidization). The second aspect focuses on the fact that pyramidal ownership and business groups can be ways to deviate from the one share-one vote principle (Nicodano, 1998) and help ultimate owners and managers to extract private benefits of control. The last aspect puts these forms of ownership into the same context as dual class shares.

Buysschaert, Deloof, and Jegers (2005) show that accounting performance in Belgian business groups is significantly lower than that of similar stand-alone firms and attribute this fact to inefficient allocation of capital within groups. However, the same authors (Buysschaert, Deloof, and Jegers, 2004) also provide evidence based on equity sales that Belgian business groups do not expropriate minority shareholders. Rather, share issues seem to serve the creation of more transparent group structures, suggesting that traditional structures may have become obsolete.

Cronqvist and Nilsson (2003) analyze accounting performance as well as stock market valuations of almost all Swedish firms in the 1990s and argue that Sweden uses more dual class shares, more cross-shareholdings, and more stock pyramids than most other countries. They find that the control of vote ownership by controlling minority shareholders is costly and reduces Tobin's Q by 6\%-25\%. Holmen and Knopf (2004) focus on mergers in Sweden where pyramids and dual class shares create situations such that shareholders have stakes in 
the bidder and the target. They find evidence for distorted acquisition decisions (lower bidder returns, more diversifying acquisitons) but little direct evidence for minority shareholder expropriation (tunneling). Boehmer (2000) analyzes takeovers by bidding firms in German business groups and finds that the presence of minority owners is associated with higher bidder returns, whereas the presence of majority owners is not, suggesting that it is difficult to empirically disentangle the monitoring role of business groups and the distortion they created. The evidence therefore suggests that minority shareholders in pyramids and business groups suffer mainly from investment decisions that benefit controlling shareholders (e. g. by reducing the likelihood of a takeover, see also Bøhren and Norli, 1997 for Norway), but are not subject to direct expropriation, which contrasts with the evidence for East Asia (see e. g. Bae, Kang, an Kim, 2002 on Korea and Bertrand, Mehta, and Mullainathan, 2002 on India) or Eastern Europe (e. g. Atanasov, 2005).

Dual class shares. The large literature on dual class shares has mainly tried to measure voting premia and to identify variables that could explain them. Most studies are singlecountry studies, which is to some extent explained by the fact that the specific institutional details that differentiate shares with superior and inferior voting rights differ across countries. Becht, Bolton, and Roell (2003) cite altogether 17 studies on mostly European countries that measure voting premia ranging from $-6.4 \%$ (Odegaard, 2002 for Norway) to 82\% (Zingales, 1994 for Italy). We do not discuss these studies here in detail (see also Rydqvist, 1992, for an earlier survey on dual class shares). Nenova (2002) presents a cross-country analysis that interprets voting premia as a measure of private benefits of control in a study of 661 companies with dual class shares from the world's 30 largest stock markets. Her measure attempts to value voting blocks rather than individual voting shares. She then applies regression analysis and enters variables that control for the probability of a control contest, block-holding costs, takeover rules, and ownership concentration. Her estimates for control 
block premia seem to agree qualitatively with the findings on voting premia from individual country studies, although the differences for some countries are large. ${ }^{10}$ All Scandinavian countries except Norway have premia of $1 \%$ and lower, whereas Italy and France have control block premia of 28-29\%. Germany and the UK fall in between with control block premia of $9.5 \%$ and $9.6 \%$ respectively. She claims that legal indicators related to investor protection can explain about two thirds of the cross-sectional variation in voting premia, which supports the notion that her control block premia are related to private benefits of control and investor protection. Note, however, from the figures reported above that the correlation between her control block premia and the common law / civil law divide seems to be weak at best.

Neumann (2003) advances a different hypothesis on voting premia that particularly addresses the fact that for some companies the superior voting shares trade at significant discounts to their non-voting counterparts. In his study of Danish stocks he shows that these discounts are related to liquidity variables and trading costs. It seems that superior voting stocks are more closely held, which makes them less liquid, more expensive to trade, and ultimately worth less. This might also explain the related observation that registered shares rose and bearer shares fell in value (so that prices converged) after the Swiss company Nestlé announced that it would allow foreign investors to trade in its stock (Loderer and Jacobs, 1995). ${ }^{11}$

Business groups, pyramids, and dual-class share structures all present different strategies for large shareholders to increase their control rights relative to their cash flow rights. However, their consequences are often less dramatic than expected. Overall, these deviations from the

10 Nenova (2002) finds 9.5\% for Germany (compared to 26.3\% in Hoffmann-Burchardi, 1999), 6.3\% for Norway (compared to $-6.4 \%$ in Odegaard, 2002) and $47.7 \%$ for Korea (compared to $10 \%$ in Chung and Kim, 1999).

11 This explanation would also be supported by Gardiol, Gibson-Asner, and Tuchschmid (1997). 
one-share one-vote principle seem to become less prevalent, another area where practice in Europe appears to converge to that of the U.S..

\section{Valuation and cost of capital}

There are only few contributions that have analyzed specifically European aspects of valuation and the cost of capital, although the U.S.-literature on these subjects is large. Bris, Koskinen, and Nilsson (2003) document that the introduction of the Euro as a common currency has increased corporate valuations by an average of $7.4 \%$ compared to those European countries (the Scandinavian countries, Switzerland, and the UK) that did not. The authors argue that this can be attributed to two channels: firstly, reductions in the cost of capital by increased benefits from diversification (reduction in the home bias), and, secondly, by increasing cash flows as international trade is usually larger in common currency areas. The effect is concentrated entirely in those countries that were subject to currency crises before the introduction of the Euro and does not apply to those countries who managed to stay within the European Monetary System. The last finding accords well with Hail and Leuz (2004), who find that conventional risk factors and macroeconomic variables like inflation explain almost $60 \%$ of the cross-sectional variation in the cost of capital in a study of 40 countries (of which 16 are European).

\section{Conclusion}

One of the major themes of this survey is the continuing heterogeneity of Europe. Apart from the LLSV-categorization (common law vs. civil law), we referred to the North-South-divide (Rajan and Zingales, 2003), the monetary divide (inside / outside the European monetary system), and we barely looked at the continuing differences between East and West and the (shifting) divide between countries inside and outside the EU. Repeatedly, we found that the legal approach developed by LLSV has only a limited capacity to capture the relevant 
differences within Europe with respect to corporate finance. However, as of now, no coherent alternative has emerged and the question of which analytic approach best captures the heterogeneity of Europe with respect to the development of equity primary markets, privatization mechanisms, the construction of business groups, and the value generated through M\&A-activity remains on the research agenda. While European practice seems to be different in some areas of corporate finance, we have indicated several areas where the gap to U.S. practice appears to be narrowing overall.

Little research addresses specifically European issues in corporate finance. We can think of several reasons for this sparseness. The diversity of institutional systems and languages presents a non-trivial barrier for researchers. To the extent that European practices are less market-based than in the U.S., they are also less observable. More subtly perhaps, most of the stylized facts that have informed corporate finance theory are rooted in U.S. empirical evidence. Theories relevant for the European context are less developed, and in turn, European research in corporate finance benefits from little theoretical guidance.

While the complexity and heterogeneity of Europe are real, a small number of recent studies (we cited Faccio and Lang, 2002, and Goergen and Renneboog, 2004, among others) use the cross-sectional variation available by looking at pan-European panels of companies. We feel that more research along these lines is needed to increase our understanding of European corporate finance. 


\section{References}

Aktas Nihat; Eric de Bodt; Levasseur Michel, and Schmitt André, 2001, The Emerging Role of the European Commission in Merger and Acquisition Monitoring: The BoeingMcDonnell Douglas Case, European Financial Management 7, no. 4 (December), pp. 447-480

Aktas, Nihat; Eric de Bodt, and Richard Roll, 2004, European M\&A Regulation Is Protectionist, Mimeo, Universite Catholique De Louvain and UCLA, (March)

- 2004, Market Response to European Regulation of Business Combinations, Journal of Financial and Quantitative Analysis 39, no. 4 (December), pp. 731-757

Amihud, Yakov and Maurizio Murgia, 1997, Dividends, Taxes, and Signaling: Evidence From Germany, Journal of Finance, 397-408.

Atanasov, Vladimir, 2005, How Much Value Can Blockholders Tunnel? Evidence From the Bulgarian Mass Privatization Auctions, Journal of Financial Economics 76, no. 1 (April), pp. 191-234

Bae, Kee-Hong; Jun-Koo Kang, and Jin-Mo Kim, 2002, Tunneling or Value Added? Evidence From Mergers by Korean Business Groups, Journal of Finance 57, pp. 2695-2740

- 2002, Tunneling or Value Added? Evidence From Mergers by Korean Business Groups, Journal of Finance 57, no. 6 (December), pp. 2695-2740

Baker, H. Kent; John R. Nofsinger, and Daniel G. Weaver, 2002, International Cross-Listing and Visibility, Journal of Financial and Quantitative Analysis 37, no. 3 (September), pp. 495521

Bancel, Franck; Nalinaksha Bhattacharyya, and Usha R. Mittoo, 2005, Cross-Country Determinants of Payout Policy: A Survey of European Firms, Working Paper, (March)

Bancel, Franck, and Usha R. Mittoo, 2004, Cross-Country Determinants of Capital Structure Choice: A Survey of European Firms., Financial Management 33, no. 4 (Winter), pp. 103132

2001, European Managerial Perceptions of the Net Benefits of Foreign Stock Listings, European Financial Management 7, no. 2 (June), pp. 213-236

Becht, Marco, Patrick Bolton, and Ailsa Roell, 2003, Corporate Governance and Control, in: Constantinides, George M., Milton Harris; and Rene M. Stulz: Handbook of the Economics of Finance, Volume 1A: Corproate Finance, Amsterdam et. al. (Elsevier North Holland)

Benveniste, Lawrence M., and Paul A. Spindt, 1989, How Investment Bankers Determine the Offer Price and Allocation of New Issues, Journal of Financial Economics 24, no. 2 (October), pp. 343-361

Bertrand, Marianne; Paras Mehta, and Sendhil Mullainathan, 2002, Ferreting Out Tunneling: An Application to Indian Business Groups, Quarterly Journal of Economics 117, no. 1 (February), pp. 121-148 
- 2002, Ferreting Out Tunneling: An Application to Indian Business Groups, Quarterly Journal of Economics 117, (February), pp. 121-148

Biais, Bruno; Peter Bossaerts, and Jean-Charles Rochet, 2002, An Optimal IPO Mechanism, Review of Economic Studies 69, no. 1 (January), pp. 117-146

Biais, Bruno, and Anne Marie Faugeron-Crouzet, 2002, IPO Auctions: English, Dutch, ...French, and Internet, . Journal of Financial Intermediation 11, no. 1 (January), pp. 9-36

Biais, Bruno, and Enrico Perotti, 2002, Machiavellian Privatization, American Economic Review 92, no. 1 (March), pp. 240-258

Boehmer, Ekkehart, 2000, Business Groups Bank Control, and Large Shareholders: An Analysis of German Takeovers, Journal of Financial Intermediation 9, pp. 117-148

Bohren, Oyvind, and Oyvind Norli, 1997, Determinants of Intercorporate Shareholdings, European Finance Review 1, no. 2 (January), pp. 265-287

Bortolotti, Bernardo, and Mara Faccio, 2004, Reluctant Privatization, ECGI - Finance Working Paper, no. 40 (October)

Bortolotti, Bernardo; Marcella Fantini, and Domenico Siniscalco, 2004, Privatisation Around the World: New Evidence From Panel Data, Journal of Public Economics 88, no. 1/2 (January), pp. 305-332

Brav, Alon; John R. Graham; Campbell R. Harvey, and Roni Michaely, 2004, Payout Policy in the 21st Century, NBER Working Papers, no. 9657 (June)

Brennan, Michael, and Avanidhar Subrahmanyam, 1996, Market Microstructure and Asset Pricing: On the Compensation for Illiquidity in Stock Returns, Journal of Financial Economics 41, pp. 441-464

Bris, Arturo Koskinen Yrjö Nilsson Matthias, 2003, The Euro Is Good After All: Evidence From Corporate Valuations, CEPR Discussion Paper Series, no. 3910 (May)

Brounen, Dirk; De Jong, Abe, and Koedijk, Kees, 2004, Corporate Finance in Europe: Confronting Theory with Practice, Financial Management 33, (4): 71

Buysschaert An; Marc Deloof, and Marc Jegers, 2004, Equity Sales in Belgian Corporate Groups: Expropriation of Minority Shareholders? A Clinical Study, Journal of Corporate Finance 10, (January), pp. 81-103

Buysschaert, An; Marc Deloof, and Marc Jegers, 2005, Is Group Affiliation Profitable in Developed Countries? Not in Belgium, Mimeo, Vrije Universiteit Brussel, (June)

Chen, H.-C., and Jay R. Ritter, 2000, The Seven Percent Solution, Journal of Finance 55, no. 3 (June), pp. 1105-1131

Chung, Kee H., and Jeong-Kuk Kim, 1999, Corporate Ownership and the Value of a Vote in an Emerging Market, Journal of Corporate Finance 5, pp. 35-54. 
Coffee, John C., 1999, The Future As History: the Prospects for Global Convergence in Corporate Governance and Its Implications, Northwestern University Law Review 93, (3), pp. 641-708

Constantinides, George M., Milton Harris, and Rene M. Stulz, 2003, Handbook of the Economics of Finance, Volume 1A: Corporate Finance, Amsterdam et. al. (Elsevier North Holland)

Cornelli, Francesca, and David Goldreich, 2001, Bookbuilding and Strategic Allocation, Journal of Finance 56, no. 6 (December), pp. 2337-2369

— 2003, Bookbuilding: How Informative Is the Order Book? Journal of Finance 58, no. 4 (August), pp. 1415

Cornelli, Francesca; David Goldreich, and Alexander P. Ljungqvist, 2004, Investor Sentiment and Pre-Issue Markets, C.E.P.R. Discussion Papers, no. 4448

Cronqvist, Henrik, and Mattias Nilsson, 2003, Agency Costs of Controlling Minority Shareholders, Journal of Financial and Quantitative Analysis 38, no. 4 (December), pp. 695719

D'Souza, Juliet, and William L. Megginson, 1999, The Financial and Operating Performance of Privatized Firms During the 1990s, Journal of Finance 54, no. 4 (August), pp. 1397-1438

Degeorge, François, and François Derrien, 2001, Les Déterminants De La Performance $\dot{r}$ Long Terme Des Introductions En Bourse: Le Cas Français, Banque Et Marchés NovemberDecember, (July), pp. 8-18

Degeorge, François; François Derrien, and Kent L. Womack, 2005, Analyst Hype in IPOs: Explaining the Popularity of Book-Building, forthcoming, Review of Financial Studies.

Degeorge, François; Dirk Jenter; Alberto Moel, and Peter Tufano, 2004, Selling Company Shares to Reluctant Employees: France Telecom's Experience, Journal of Financial Economics 71, no. 1 (January), pp. 169-202

Derrien, François, 2005, IPO Pricing in "Hot" Market Conditions: Who Leaves Money on the Table?, Journal of Finance 60, no. 1 (February), pp. 487-521

Derrien, François, and Ambrus Kecskes, 2005, The Initial Public Offerings of Listed Firms, Working Paper, (June)

Derrien, François, and Kent L. Womack, 2003, Auctions Vs. Bookbuilding and the Control of Underpricing in Hot IPO Markets, Review of Financial Studies 6, no. 1 (Spring), pp. 31-61

Doigde, Craig; G. Andrew Karolyi; Karl V. Lins; Darius P. Miller, and Rene M. Stulz, 2005, Private Benefits of Control, Ownership, and the Cross-Listing Decision, NBER Working Paper, no. 11162 (March)

Doigde, Craig; G. Andrew Karolyi, and Rene M. Stulz, 2001, Why Are Foreign Firms Listed in the U.S. Worth More?, NBER Working Paper, no. 8538 (October) 
Encaoua, David, and Alexis Jacquemin, 1982, Organizational Efficiency and Monopoly Power: the Case of French Industrial Groups, European Economic Review 19, pp. 25-51

Faccio, Mara, and Larry H. P. Lang, 2002, The Ultimate Ownership of Western European Corporations, Journal of Financial Economics 65, no. 3 (September), pp. 365-395

Fama, Eugene F., and Kenneth R. French, 2004, New Lists: Fundamentals and Survival Rates, Journal of Financial Economics 73, no. 2 (August), pp. 229-269

Focarelli, Dario, and Fabio Panetta, 2003, Are Mergers Beneficial to Consumers? Evidence From the Market for Bank Deposits, The American Economic Review 93, no. 4, pp. 11521172

Ginglinger, Edith and Hamon, Jaques, 2005, Actual Share Repurchases, Timing and Corporate Liquidity, mimeo, Universite Paris-Dauphine

Goergen, Marc, and Luc Renneboog, 2004, Shareholder Wealth Effects of European Domestic and Cross-Border Takeover Bids, European Financial Management 10, no. 1 (March), pp. 9-45

Goergen, Marc; Luc Renneboog, and Luis Correia da Silva, 2005, When Do German Firms Change Their Dividends? . Journal of Corporate Finance 11, no. 1/2 (March), pp. 375-399

Graham, John R., and Campbell R. Harvey, 2001, The Theory and Practice of Corporate Finance: Evidence From the Field, Journal of Financial Economics 60, no. 2/3 (May/June), pp. 187-243

Gugler, Klaus, and Burcin B. Yurtoglu, 2004, The Effects of Mergers on Company Employment in the USA and Europe, International Journal of Industrial Organization 22, no. 4 (April), pp. 481-502

Hail, Luzi, and Christian Leuz, 2004, International Differences in Cost of Equity Capital: Do Legal Institutions and Securities Regulation Matter?, ECGI Law Working Paper, no. 15/2003 (May)

Hansen, Robert S., 2001, Do Investment Banks Compete in IPOs?: The Advent of the '7\% Plus Contract', Journal of Financial Economics 59, no. 3 (March), pp. 313-346

Holmen, Martin, and John D. Knopf, 2004, Minority Shareholder Protections and the PrivateBenefits of Control for Swedish Mergers, Journal of Financial and Quantitative Analysis 39, no. 1 (March), pp. 167-191

Högholm, Kenneth, and Kristian Rydqvist, 1995, Going Public in the 1980s - Evidence From Sweden, European Financial Management 1, no. 3, pp. 287-315

Jenkinson, Tim, and Howard Jones, 2004, Bids and Allocations in European IPO Bookbuilding, . Journal of Finance 59, no. 5 (October), pp. 2309-2338

Jones, Steven L.; William L Megginson; Robert C. Nash, and Jeffry M. Netter, 1999, Share Issue Privatizations As Financial Means to Political and Economic Ends, Journal of Financial Economics 53, no. 2 (August), pp. 217-253 
Keloharju, Matti; Samuli Knüpfer, and Sami Torstila, 2005, Do Retail Incentives Work in Privatizations?, EFA 2004 Maastricht Meetings Paper, no. 04688 (January)

La Porta, Rafael; Florencio Lopez-De-Silanes; Andrei Shleifer, and Robert W. Vishny, 1998, Law and Finance, The Journal of Political Economy 106, no. 6 (December), pp. 1113-1155

La Porta, Rafael; Florencio Lopez-De-Silanes; Andrei Shleifer, and Robert W. Vishny, 1997, Legal Determinants of External Finance, Journal of Finance 52, no. 2 (July), pp. 1131-1150

Licht, Amir N., 2001, Managerial Opportunism and Foreign Listing: Some Direct Evidence, Working Paper, (January), pp. 32

Ljungqvist, Alexander P.; Tim Jenkinson, and William J. Wilhelm, 2003, Global Integration in Primary Equity Markets: The Role of U.S. Banks and U.S. Investors, Review of Financial Studies 16, no. 1 (Spring), pp. 63-99

Loderer, Claudio, and Andreas Jacobs, 1995, The Nestle Crash, Journal of Financial Economics 37, no. 3 (March), pp. 315-339

Loughran, Tim, and Jay R. Ritter, 1995, The New Issues Puzzle, Journal of Finance 50, no. 1 (March), pp. 23-51

Megginson, William L., and Jeffry M. Netter, 2001, From State to Market: A Survey of Empirical Studies on Privatization, Journal of Economic Literature 39, no. 2 (June), pp. 321289

Morrison, Alan; Tim Jenkinson, and William J. Wilhelm, 2003, Why Are European IPOs So Rarely Priced Outside the Indicative Price Range?, Mimeo, University of Virginia, (March)

Nenova, Tatiana, 2002, The Value of Corporate Votes and Control Benefits: A CrossCountry Analysis, Journal of Financial Economics 68, no. 3 (June), pp. 325-351

Neumann, Robert, 2003, Price Differentials Between Dual-Class Stocks: Voting Premium or Liquidity Discount?, European Financial Management 9, no. 3 (September), pp. 315-332

Nicodano, Giovanna, 1998, Corporate Groups, Dual-Class Shares and the Value of Voting Rights, Journal of Banking and Finance 22, no. 9 (September), pp. 1117-1137

Odegaard, B. A., 2002, Price Differences Between Equity Classes. Corporate Control, Foreign Ownership or Liquidity? Evidence From Norway, Mimeo, Norwegian School of Managment

Odegaard, Bernt Arne, 2003, Price Differences Between Equity Classes Corporate Control, Foreign Ownership or Liqudity? Evidence From Norway

Pagano, Marco; Fabjo Panetta, and Luigi Zingales, 1998, Why Do Companies Go Public? An Empirical Analysis, Journal of Finance 53, no. 1 (February), pp. 27-64

Pagano, Marco; Otto Randl; Alisa A. Röell, and Josef Zechner, 2001, What Makes Stock Exchanges Succeed? Evidence From Cross-Listing Decisions, European Economic Review 45, (4-6), pp. 770-782 
Portes, Richard; Hélene Rey, and Yonghyup Oh, 2001, Information and Capital Flows: The Determinants of Transactions in Financial Assets, European Economic Review 45, pp. 783796

Purnanandam, Amiyatosh K., and Bhaskaran Swaminathan, 2004, Are IPOs Really Underpriced?, The Review of Financial Studies 17, no. 3 (Fall), pp. 811-848

Rajan, Raghuram G., and Luigi Zingales, 2003, Banks and Markets: The Changing Character of European Finance, NBER Working Papers, no. 9595 (January)

- 2003, The Great Reversals: the Politics of Financial Development in the Twentieth Century, Journal of Financial Economics 69, pp. 5-50

Rajan, Raghuram G, and Luigi Zingales, 1995, What Do We Know About Capital Structure? Some Evidence Form International Data, Journal of Finance 50, no. 5 (December), pp. 14211460

Reese, William A., and Michael S. Weisbach, 2002, Protection of Minority Shareholder Interests, Cross-Listings in the United States, and Subsequent Equity Offerings, Journal of Financial Economics 1, no. 66 (10), pp. 65-104

Rydqvist, Kristian, 1992, Dual-Class Shares: A Review, Oxford Review of Economic Policy 8, pp. $45-57$

Sarkissian, Sergei, and Michael J. Schill, 2004, The Overseas Listing Decision: New Evidence of Proximity Preference, The Review of Financial Studies 17, no. 3, pp. 769-809

Saudagaran, Shahrokh M., 1988, An Empirical Study of Selected Factors Influencing the Decision to List on Foreign Stock Exchanges, Journal of International Business Studies 19, no. 1, pp. 101-128

Sherman, Ann E., 2004, Global Trends in IPO Methods: Book Building Vs. Auctions With Endogenous Entry, Working Paper, (December)

Siegel, Jordan, 2005, Can Foreign Firms Bond Themselves Effectively by Renting U.S. Securities Laws?, Journal of Financial Economics 75, no. 2, pp. 319-359

Tolmunen, Pasi, and Sami Torstila, 2005, Cross-Listings and M\&A Activity: Transatlantic Evidence, Financial Management 34, no. 1 (February), pp. 123-142

Wilhelm, William J.; Alan D. Morrison, and Tim Jenkinson, 2003, Why Are European IPOs So Rarely Priced Outside the Indicative Price Range?, Oxford Financial Research Center Working Paper, no. 2003-FE-05

Zingales, Luigi, 1994, The Value of the Voting Right: A Study of the Milan Stock Exchange Experience, The Review of Financial Studies 7, no. 1, pp. 125-148 